A. Yakimov, L. Bovnegra, S. Uminsky, V. Tonkonogyi, Y. Shichireva, Odessa, Ukraine

\title{
WEAR GRINDING WHEELS WITH PRECISE WORKING SURFACE
}

\begin{abstract}
The use of circles with an intermittent working surface is an effective means of increasing productivity and reducing the heat stress of the grinding process. These positive effects are largely determined by the appearance of high-frequency oscillations in the elastic system of the machine, which facilitate the chip formation process and create conditions for continuous selfformation of the cutting microrelief of the working surface of the abrasive tool. However, for certain aggregates of rigidity of the elastic system of the machine, geometric parameters of the macrorelief of the working surface of an intermittent circle, and parameters of the cutting mode, parametric resonance may occur, which is accompanied by catastrophic wear of an abrasive tool and a deterioration in the geometric and physical-mechanical characteristics of the quality of the surface layer of the workpiece. The aim of the work is to study the influence of grinding mode parameters and geometric parameters of the working surface of intermittent abrasive wheels on their dimensional and linear wear, as well as identifying areas of their rational use. It was found that oscillations during intermittent grinding caused by parametric resonance can be significantly reduced or eliminated completely by increasing the rigidity of the elastic system of the machine, using discontinuous circles of a certain geometry, and increasing the peripheral speed of the circle. Based on the experiments to determine the specific wear of the elbore dashed circles, the expediency of their use in deep encryption is substantiated. $t$ is established that to increase dimensional stability of an abrasive tool it is necessary to increase the circular velocity to $40 \mathrm{~m} / \mathrm{s}$ and to provide in the machines the possibility of preserving the constancy of the circular velocity of the circle as it is worn.
\end{abstract}

Keywords: dimension wear; specific wear; intermittent grinding; steady grinding; creep feed (deep) grinding; cutting projections.

Introduction. When grinding the actual cutting depth is always less than the depth established by the limb of the machine. This is due to the lack of rigidity of the elastic system of the machine, the abrasive wheel wear and decrease its cutting ability. The higher the cutting capacity of the grinding wheel and the rigidity of technological system and the smaller dimension of the abrasive wear of the tool, the less time you can achieve the required accuracy of processing parameters. Dimensional wear circles with intermittent work surface More wear normal (solid) circles. This is selfsharpen discontinuous circles. Selfsharpen abrasive tool increases its resistance, i.e., increasing the time between corrections, but excessive selfsharpen reduces the dimensional stability of the circle and, consequently, to reduce the time between corrections. Reducing the time between revisions reduces grinding performance. The problem of reducing the size of the abrasive tool is considered in papers [1-8]. 
Due to the difficulty of assessing the role of individual factors on the radial wear of abrasive wheels in a discontinuous grinding, this problem is still relevant.

The purpose of research: To study the effect of grinding mode settings and the size of geometric elements of the working surface of the discontinuous grinding wheels to their dimension and the specific wear.

The results of research. When grinding dotted circles there is a periodic change in the stiffness of the elastic system for surface grinding machines, leading to the emergence of parametric resonance. As a result of visiting the elastic large amplitude vibrations of the machine system of intermittent abrasive circle begins to operate in a catastrophic wear mode, followed by the burn marks and undulation on the treated surfaces. On fig. 1. 2, 3 showing zones of parametric instability of elastic system of surface grinding machines (humps) and sustainable grinding (gaps between the humps), calculated at intervals of change numbers of the cutting projections $0 \leq n \leq 160$ (a) and the ratio of cavities $l_{2}$ to the arm of the sizes $l_{1} 0,325 \leq l_{2} / l_{1} \leq 0,450$ (b) with the formulas [9].

$$
|L|>\frac{1+M}{2}
$$

Where

$$
\begin{array}{r}
L=\frac{e^{-h\left(\tau_{1}+\tau_{2}\right)}}{h\left(k_{2}+h \sin 2 k_{2} \tau_{1}\right)}\left[k_{1}^{2} \sin k_{1} \tau_{1} \sin k_{2} \tau_{2}-\right. \\
-2 \cdot k_{1} \cdot k_{2} \cdot \cos k_{2} \tau_{1} \cdot \cos k_{1} \tau_{1} \cdot \cos k_{2}\left(\tau_{1}+\tau_{2}\right)- \\
\left.-k_{2}^{2} \sin k_{1} \tau_{1} \sin \left(2 \cdot k_{2} \tau_{1}+k_{2} \tau_{2}\right)\right] \\
M=\frac{k_{1} k_{2} e^{-2 h\left(\tau_{1}+\tau_{2}\right)} \cos \left(2 \cdot k_{2} \cdot\left(\tau_{1}+\tau_{2}\right)\right)}{h\left(k_{2}+h \sin 2 k_{2} \tau_{1}\right)}
\end{array}
$$

$\tau_{1}, \tau_{2}$ - propagation times over the projections and depressions discontinuous circle treated surface, $s$;

$$
k_{1}=\sqrt{\frac{C_{o}}{m}+\frac{C_{o} \cdot\left(\frac{t_{n}}{t_{\phi}}-1\right)}{2 \cdot m}-h^{2}}, \quad k_{2}=\sqrt{\frac{C_{o}}{m}-\frac{C_{o} \cdot\left(\frac{t_{n}}{t_{\phi}}-1\right)}{2 \cdot m}-h^{2}} ;
$$

$t_{\pi}$ - cutting depth, set the limb, m; $t_{\phi}-$ the actual depth of cut, m; $C_{o}-$ given the rigidity of the elastic system of the machine, $\mathrm{N} / \mathrm{m} ; h$ - quantity that characterizes the extinction of oscillations in time, $1 / \mathrm{s}$. $m$ - reduced mass of the grinding wheel, $\left(\mathrm{N} \cdot \mathrm{s}^{2}\right) / \mathrm{m}$. The calculations were performed for different 
values of the reduced stiffness $C_{0}: C_{0}=0,3 \cdot 10^{6} \mathrm{n} / \mathrm{m}$ (fig. 1 ), $C_{0}=2 \cdot 10^{6} \mathrm{n} / \mathrm{m}$ (fig.2), $C_{0}=3,5 \cdot 10^{6} \mathrm{n} / \mathrm{m}$ (fig.3).

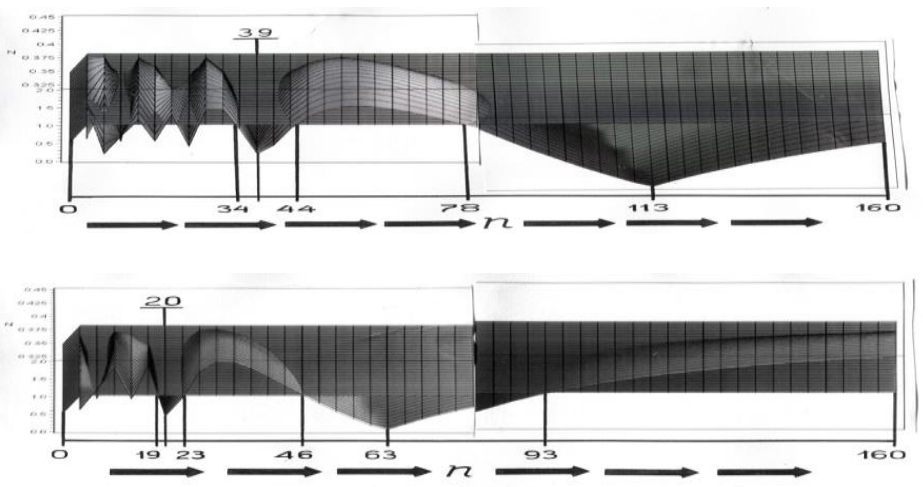

Figure 1 - Zones of parametric instability of elastic system of the machine (hills), built at intervals $0 \leq n \leq 160,0,325 \leq N \leq 0,450$,for $V_{\text {circle }}=25 \mathrm{~m} / \mathrm{s}$ (top row),

$$
V_{\text {circle }}=40_{\mathrm{m} / \mathrm{s} \text { (bottom row) }} C_{0}=0,5 \cdot 10^{6} \mathrm{n} / \mathrm{m} \text {. }
$$
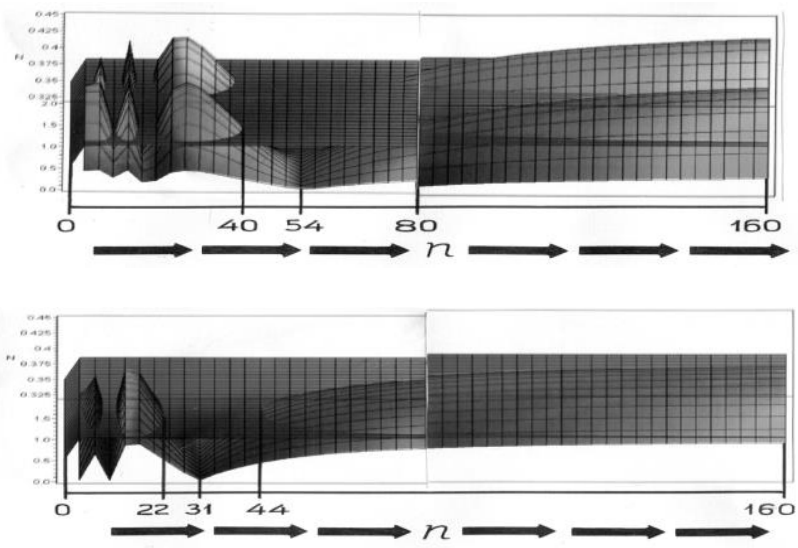

Figure 2 - Zones of parametric instability of elastic system of the machine (hills), built at intervals $0 \leq n \leq 160,0,325 \leq N \leq 0,450$, for $V_{\text {circle }}=25 \mathrm{~m} / \mathrm{s}$ (top row),

$$
V_{\text {circle }}=40 \mathrm{~m} / \mathrm{s} \text { (bottom row) } C_{0}=2 \cdot 10^{6} \mathrm{n} / \mathrm{m}
$$



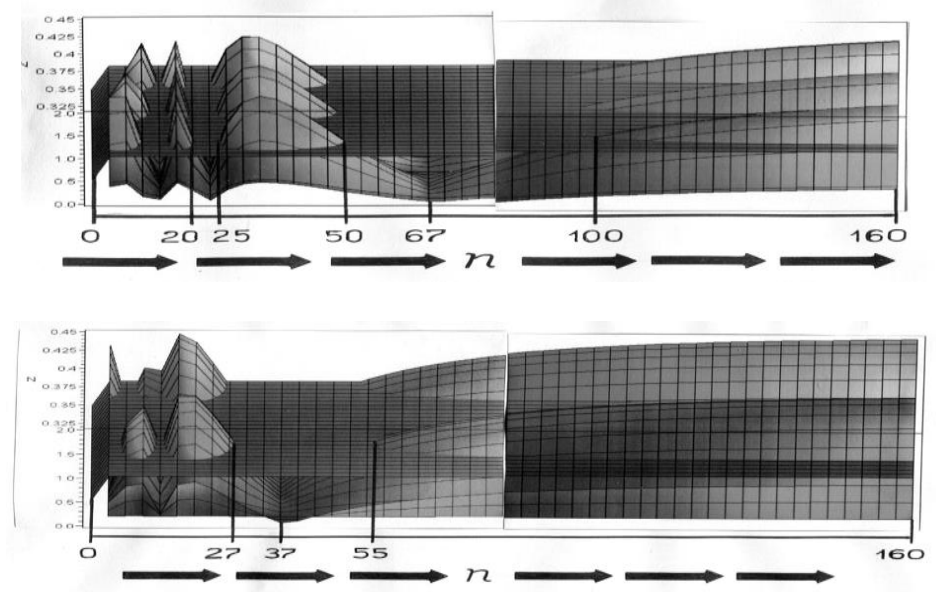

Figure 3 - Zones of parametric instability of elastic system of the machine (hills), built at intervals $0 \leq n \leq 160,0,325 \leq N \leq 0,450$, for $V_{\text {circle }}=25 \mathrm{~m} / \mathrm{s}$ (top row),
$V_{\text {circle }}=40 \mathrm{~m} / \mathrm{s}$ (bottom row) $C_{0}=3,5 \cdot 10^{6} \mathrm{n} / \mathrm{m}$.

From Figure 1, 2, 3 shows that with an increase in stiffness of the elastic system $C_{0}$ dimensions of the regions sustainable grinding were measured along the axis, extended, and areas themselves are displaced in the direction of increasing the number of slots on the wheel. From Figure 1, 2, 3 (b) shows that an increase in stiffness $C_{0}$ parametric stability number of zones in the axial direction $N$ increases and their size decreases. From Figure 1, 2, 3, it is seen that with increasing speed $V_{k p}$ dimensions of the regions sustainable grinding were measured along the axis $n$.

Analysis of Figure 1, 2, 3 allowed to build charts $\Delta n=f\left(C_{0}\right)$ and $n_{c p}=f\left(C_{0}\right)$ for wheel peripheral speed $V_{k p}=25 \mathrm{~m} / \mathrm{s}$ and $V_{k p}=40 \mathrm{~m} / \mathrm{s}$, where: $\Delta n-$ Interval numbers intermittent cutting projections on the circle that defines the width of the zone of stable grinding; $n_{c p}$ - cutting the number of projections corresponding to the minimum value $L$ on the interval $\Delta n$. Graphs are shown in Figure 4. 


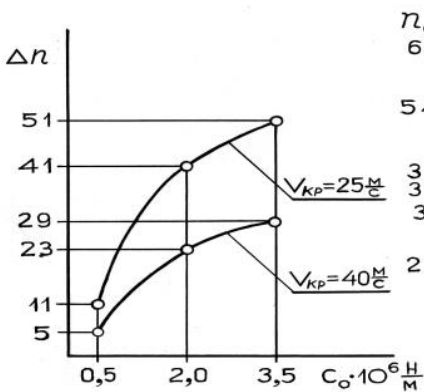

a

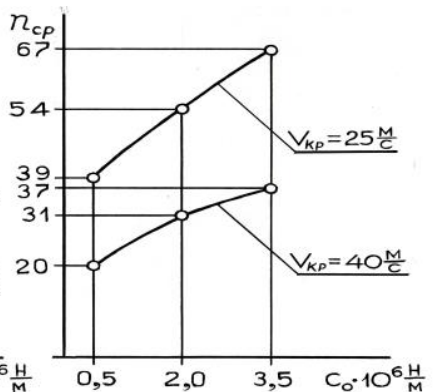

$\mathrm{b}$

Figure 4 - Charts showing the nature of the increase $\Delta n$ (a) and $n_{\text {medium }}$ (b) reduced with increasing hardness $C_{0}$ elastic system machine for $V_{\text {circle }}=25 \mathrm{~m} / \mathrm{s}$ and

$$
V_{\text {circle }}=40 \mathrm{~m} / \mathrm{s}
$$

From the analysis of Figure 4 (b) that due to the cutting speed $V_{k p}$ you can achieve a significant reduction on the number of intermittent slits circles that reduces their cost.Increasing the value of intermittent abrasive wheels with the number of slots is due to the imperfection of their production technology: the grooves are cut on the grinding machines equipped with the divider.. Increasing the value intervals $N$, equal to the ratio cavities sizes $l_{2}$ to the lengths of the projections $l_{1}$, reduces the probability of exit from the zone of steady grinding due to the reduced length of the cutting projection associated with the formation on it "front" section (Figure 5) $[10,11]$ and a decrease in the diameter of the circle, caused by wear and tear of the last line (Figure 6).

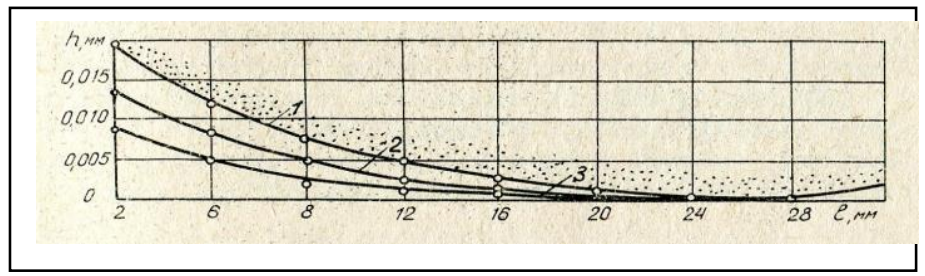

Figure 5 - Dependence of wear on cutting length performances of rigidity spindle unit

( $V_{\text {circle }}=25 \mathrm{~m} / \mathrm{s}, V_{\text {det } a i l}=10 \mathrm{~m} / \mathrm{min} ., t=0,03 \mathrm{~mm} /$ table course, round

24A25CM1K1): $1-C_{\text {specific }}=300 \mathrm{~kg} / \mathrm{mm} ; 2-C_{\text {specific }}=625 \mathrm{~kg} / \mathrm{mm}$;

$$
3-C_{\text {specific }}=1000 \mathrm{~kg} / \mathrm{mm} \text {; }
$$




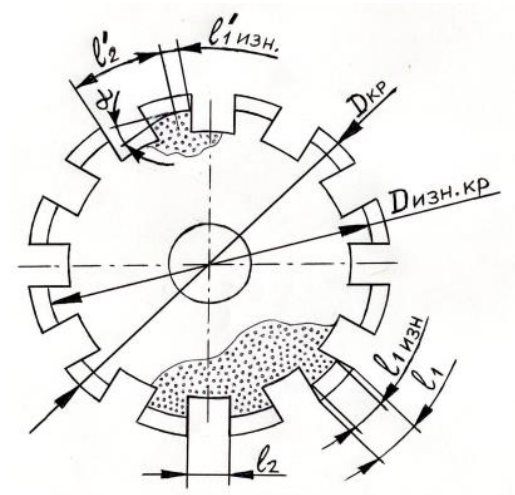

Figure 6 - Reducing the length of the cutting performance of intermittent grinding wheel in its linear wear

Furthermore, with increasing peripheral speed range of $V_{k p}$ it decreases wear (Figure 7) [10], which contributes to maintaining the ratio $N=l_{2} / l_{1}$ and, consequently, reduce the probability of the output stable grinding zone.
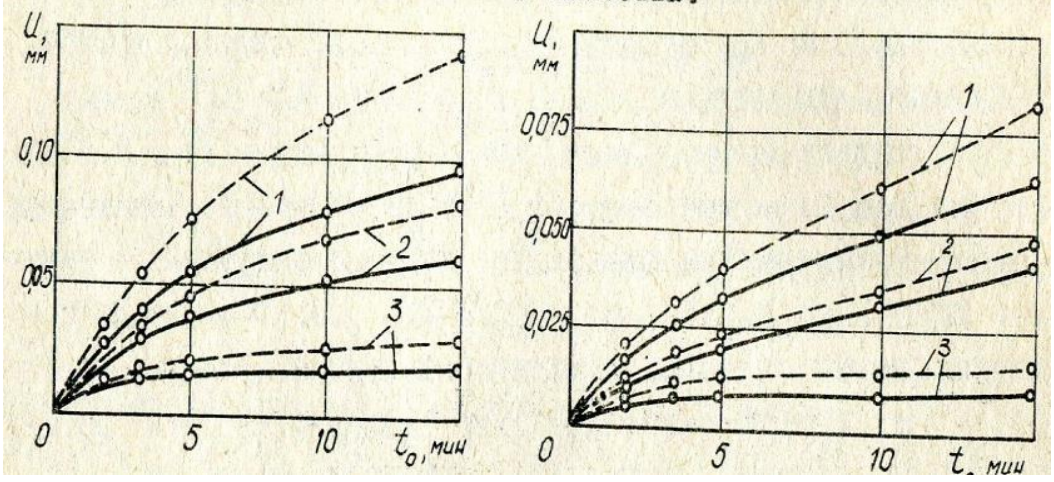

Figure 7 - Effect wheel peripheral speed to wear it without loading the grinding unit and the previous loading (b) $P=25 \mathrm{~kg}: 1 \quad V_{\text {circle }}=16 \mathrm{~m} 2 V_{\text {circle }}=25 \mathrm{~m} / \mathrm{s}$;

$3 V_{\text {circle }}=35 \mathrm{~m} / \mathrm{s} ;\left(V_{\text {det } a i l}=10 \mathrm{~m} / \mathrm{min}\right.$; $t=0.03 \mathrm{~mm} /$ table course $)$; Dashed lines intermittent grinding; Solid lines - a complete grinding 
In grinding with a large depth and a lack of wheel peripheral speed is increased in the loss of grains and, as a consequence, the correct geometrical form is broken circle. In the process of grinding vibration occurs and the range must be part of the right to recover form. To improve dimensional stability circles necessary to increase the circumferential speed range up to $40 \mathrm{~m} / \mathrm{s}$ and provide the opportunity to save machining wheel peripheral speed constancy as it is worn.

Figure 5 shows the dependence of the wear on the cutting length of the projection of the stiffness of the spindle angle. With intermittent grinding during the passage of the depression over the nip part is moved by a certain amount. This causes an increase in the volume of metal removed by separate abrasive grains located near the front edge of the cutting projection. The increased impact force, these grains perceived causes their intensive and selfsharpening cutting projections are formed on "front" portions having an angle of inclination to the cutting plane [10,11].From Fig. 6, the formation of a "front" portion increases the width of the cavity by reducing the length of the cutting projection. If the cutting depth exceeds "zatylovaniya" cutting projections or equal to, the size of the protrusions and depressions are the same. The width of the cavities is increased if the cutting depth becomes less than the depth "zatylovaniya" projection. Changing the ratio between the sizes of the projections $l_{1}$ and valleys $l_{2}$ can lead to the exit from the zone of steady grinding, the size of which is determined by the interval of acceptable values $N=l_{2} / l_{1}$.From Figure 5 it is clear that with increasing rigidity spindle unit uneven wear on various sites along the length of the cutting projection is reduced by more than half, due to a decrease in the amplitude of the forced oscillation range.Dependencies size wear from time to time and various blunt wheel peripheral speed for grinding without loading the spindle unit and its loading are shown in Figure 7. [10]. Figure 8 [12] shows the dependence of the unit and the total cutting forces tangential components $(\mathrm{a}, \mathrm{b})$ grinding and surface temperature (a) from the rotational speed of the grinding wheel.

Total cutting force was calculated by the formula [12]

$$
P_{z}=5,46 \cdot\left(\frac{K_{v} \cdot \sigma \cdot A \cdot r \cdot V_{\partial} \cdot l_{\phi}}{R_{k p}}\right) \cdot\left(\frac{\varepsilon \cdot \alpha}{V_{k p}}\right)^{0,7} \cdot \tau^{0,44},
$$

where $K_{v}$ - temperature and speed ratio;

$$
K_{v}=2,74 \cdot 10^{6} \cdot V_{k p}^{0,4} ;
$$

$\sigma$ - tensile strength under static test methods; 


$$
A=\frac{\cos \gamma^{\prime}-\mu \cdot \sin \gamma^{\prime}}{\sin \theta^{\prime} \cdot\left(1-\mu \cdot \mu^{\prime}\right) \cdot \cos \left(\gamma^{\prime}+\theta^{\prime}\right)+\left(\mu+\mu^{\prime}\right) \sin \left(\gamma^{\prime}+\theta^{\prime}\right)} ;
$$

$\theta^{\prime}$ - angle of shearing; $\gamma^{\prime}$ - rake angle; $\mu$ - the coefficient of friction of the metal grains; $\mu^{\prime}-$ coefficient of internal friction during plastic deformation; $\gamma^{\prime}=\frac{1}{2} \cdot\left(\pi-\arcsin \frac{3 \cdot 10^{-6}}{\sqrt{r}}\right) ; \theta^{\prime}=45^{\circ}-\frac{\gamma^{\prime}+\mu+\mu^{\prime}}{2} ; V_{\partial}-$ rate the details; $R_{k p}-$ the radius of the grinding wheel; $\varepsilon$ - Heat metal activity coefficient; $\varepsilon=\sqrt{\lambda \cdot c \cdot \gamma} ; \lambda$ - coefficient of thermal conductivity; $c$ - specific heat; $\gamma-$ density of the processed material; $\alpha$ - thermal diffusivity; $l_{\phi}$ - the actual distance between the grains on the surface of the circle; $l_{\phi}=6,48 \cdot V_{k p}^{0,5} \cdot n_{y \partial}{ }^{-0,5} ; n_{y d}=111 \cdot 10^{6} \cdot N_{3}^{-1,3} \cdot N_{c m p}^{-0,17} ; N_{3}-$ grain number range; $N_{c m p}$ - number range structure; $r$ - radius grain microns; for white fused $r=10^{-6} \cdot N_{3}{ }^{0,85}$; for silicon carbide green $r=10^{-6} \cdot N_{3}{ }^{0,85} \cdot 1,4$; for diamond $r=0,25 \cdot 10^{-6} \cdot N_{3}^{0,85} ; \tau$ - time.

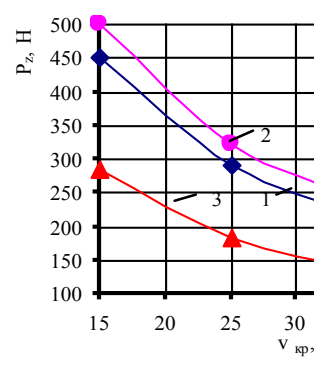

a

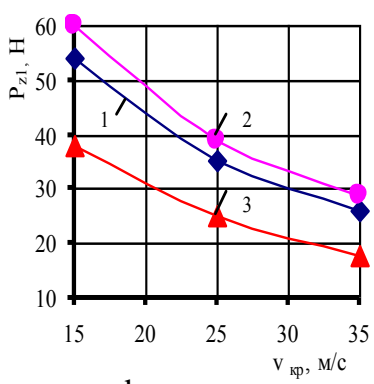

b

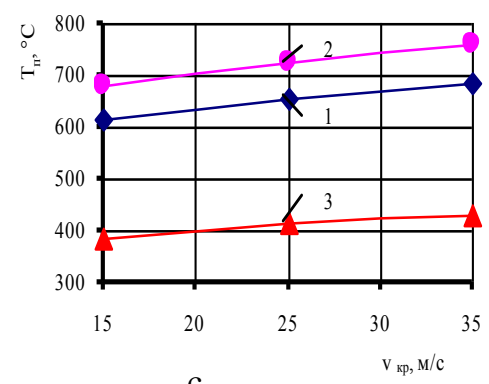

c

Figure 8 - Dependencies total cutting force (a) power unit (b), the surface temperature (c) the speed of rotation of the grinding wheel in grinding parts from composite $\mathrm{TiC}-$ $\mathrm{NiP}-\mathrm{Cu}$ - thick coating mode $h=0,5 \mathrm{~mm}$ mode $V_{\text {circle }}=15 \mathrm{~m} / \mathrm{min}$., $S=2 \mathrm{~mm} /$ double stroke, $t=0,01 \mathrm{~mm}$ circles: $1-24 \mathrm{~A} 25 \mathrm{CM} 1 \mathrm{~K} 1$, 2 - 63C40CM16K5, 3-AC4200/160 100K1 
A single force is determined by the formula

$P_{z 1}=0,6 \cdot \sigma_{\partial} \cdot f \cdot A$

$\sigma_{\partial}-$ tensile strength "dynamic", i.e. considering actions of both temperature and speed factor;

$\sigma_{\partial}=\sigma_{n \pi} \cdot \exp \left\{m \cdot\left[1773-(\theta+273) \cdot\left(0,017 \cdot l_{n} \cdot \frac{10^{3} \cdot V_{k p}}{h}\right)\right]\right\} ;$

$m-0,002$ (for steel); $\sigma_{n л}-$ tensile strength at the melting temperature;

$f=\frac{2 \cdot \pi \cdot r \cdot V_{\partial} \cdot l_{\phi} \cdot \tau}{R_{k p}} ; h=\frac{V_{\partial} \cdot l_{\phi} \cdot \tau}{V_{k p}} ;$

$\theta$ - the temperature of a single grain; $\theta=\frac{q \cdot \sqrt{\alpha \cdot \tau}}{f \cdot \lambda \cdot \sqrt{\pi}} \cdot\left(1-e^{-\frac{r \cdot h}{2 \cdot \alpha \cdot r}}\right)$;

$q$ - the power of the heat sourc From Figure 9 shows that with an increase in the speed range of the cutting forces occurring during the cutting edge of the grain, are reduced. This is due to a decrease in the cut section and a single grain results in a decrease of wear of the linear range. Increasing the speed range leads to a temperature increase during grinding, which can lead to deterioration of the surface layer of the treated detail.From Fig. 8(a) shows that the use of diamond wheels grinding significantly reduces temperature than abrasive blasting. A similar result is obtained when using CBN wheels [11]. It is found that after running the cutting circle profile projections become a permanent form. Regardless of the mode of grinding angle of attack of the frontal zone of discontinuous circle KR 160/125 B8 100 with 12 projections ( $\left.l_{1}=45 \mathrm{MM}, l_{2}=20,5 \mathrm{MM}\right)$ After $4-5$ - minute grinding period is $6-12^{\prime}$.

Changing the linear wear of discontinuous circles as by grinding steel R6M5 provided an opportunity to assess consumption in various modes CBN plunge grinding (Table 1).

Mode 1: $t=0,5 \mathrm{~mm}, V_{\partial}=0.3 \mathrm{~m} / \mathrm{min}$;

Mode 2: $t=1,0 \mathrm{~mm}, V_{\partial}=0.1 \mathrm{~m} / \mathrm{min}$;

Mode 3: $t=0,03 \mathrm{~mm}, V_{\partial}=6 \mathrm{~m} / \mathrm{min}$;

If creep feed grinding during the formation of the profile of the projections on the cutting laps with a broken surface of specific wear is large enough. After the running-profile cutting projections specific wear circles is constant and the wear process becomes stationary signs. In the interval 7 minute period for grinding steel R6M5 modes $1,2,3$, the average value of the 
specific wear dashed circles, respectively, the working surface is equal to: $q_{1}=3,113 \mathrm{mg} / \mathrm{g}, q_{2}=5,600 \mathrm{mg} / \mathrm{g}, q_{3}=6,114 \mathrm{mg} / \mathrm{g}$. If deep grinding solid circle KR 160/125 $100 \mathrm{G} 8$ in various modes after the removal of $75 \mathrm{~g}$ of metal average wear was $4.5 \mathrm{mg} / \mathrm{m}$. These data indicate that the specific wear depth discontinuous grinding wheels wear roughly similar specific solid circles may only vary slightly depending on the modes. However, the use of discontinuous circles for creep feed grinding more efficiently, as with their specific wear considerably less than with intermittent grinding on conventional traditional modes with small depth of grinding and high velocities moving parts.

Table 1 - Changing the linear wear of discontinuous circles as by grinding steel R6M5 provided an opportunity to assess consumption in various modes CBN plunge grinding

\begin{tabular}{|l|l|c|c|c|c|c|c|c|}
\hline \multirow{2}{*}{$\begin{array}{l}\text { Weight with } \\
\text { brushed metal, g g }\end{array}$} & Mode 1 & 9 & 18 & 27 & 36 & 45 & 54 & 63 \\
\cline { 2 - 10 } & Mode 2 & 9 & 18 & 27 & 36 & 45 & & \\
\cline { 2 - 10 } & Mode 3 & 11 & 22 & 26 & 44 & 56 & 67 & 87 \\
\hline $\begin{array}{l}\text { Consumption } \\
\text { CBN, mg/g }\end{array}$ & Mode 1 & 4,16 & 3,58 & 2,80 & 3,85 & 2,50 & 2,50 & $\begin{array}{c}2 \\
40\end{array}$ \\
\cline { 2 - 10 } & Mode 2 & 9 & 5 & 5 & 5 & 4 & & \\
\cline { 2 - 10 } & Mode 3 & 8 & 6,80 & 6 & 6 & 6 & 5 & 5 \\
\hline
\end{tabular}

Conclusions. 1. An increase in the cutting speed leads to an expansion range of values allowable width relationship to cavity length of projection in which the elastic system in a surface grinding machine parametric resonance does not occur and grinding sustainable shifts towards reducing the number of slots in the abrasive wheel. 2. Found that fluctuations with intermittent grinding caused by parametric resonance can be partially reduced or totally eliminated by increasing the rigidity of the elastic system of the machine, the use of discontinuous circles defined geometry, increasing wheel peripheral speed. 3. It was found that to improve the dimensional stability of abrasive tools necessary to increase the peripheral speed of $40 \mathrm{~m} / \mathrm{s}$ and provide the ability to save in the machines of constant grinding wheel peripheral speed as it is worn. 4. On the basis of experiments conducted to determine the specific wear «elbor» discontinuous circles the expediency of their use in creep feed grinding.

References: 1. Alekseev, N.S. Worn grinding wheels while processing microprecise covers. /N.S Alekseev // Proceedings of the universities. Mechanical Engineering. - 2004. - №2. pp. 57 - 61. 2. Belyakov, V.N. Evaluation of performance of abrasive tools /V.N. Belyakov, Y. Dubrovsky IV Shvetsov, OV Nikulenko // Tools and technology. - 2005. - № 21-22. pp. 28 -31. 3. Vorontsova, A.N. Investigation of the effect of magnitude of force acting on the wear of the grinding wheel during the grinding with constant force /A.N. Vorontsov, VV Vorontsov // News VUolgGTU. - 2004. --№ 9. pp. 12 -15. 4. Pazhitsky, E. A study of the radial wheel wear during the longitudinal grinding of external cylindrical surfaces / E. Pazhitsky // Proceedings of the International. Internet Conf. "Technological 
complexes, business equipment building materials and construction industry." - Minsk 2003. 5. Gutsalenko, Y.G. Ensuring the sustainability of diamond grinding /Y.G. Gutsaleko // Visn. Kharkiv. nats..techn. silsk the University. Gospa Island IM. Peter Vasilenko: ST. Sciences. etc. Kharkiv: HNTUST, 2006. - Vip.. 42. - pp. 246 -252. 6. Gutsalenko, Y.G. Resistance range in workflow management stable grinding // Visn. nat. techn. University the "Hark. politechn. in.- t "- 2005. - №23. - pp.50-63. 7. Owl, A.N. Effect of wear on the grinding wheel precision mold profiles. / A.N. Owl // Chemical and petroleum engineering. - 1981. - №11. - pp. 27 - 28. 8. Filin, A.N. Improving the accuracy of profile shaped surfaces at the plunge grinding by stabilizing the radial tool wear: Author. Dis. ... Doctor. techn. Sciences: 05.02.08 / Mosk. Machine Tool Institute. - Moscow, 1987. - 33 p. 9. Yakimov, O.O. Technological security of Quality surface ball racks high-precised gears at polishing: Author. Dis .... Doctor. techn. Sciences: 05.02.08 / Odes. nat. politehn. Univ. - Odessa, 2015. - 50 p. 10. Gun'ko, N.I. Investigation of the effect of rigidity on surface grinding machines grinding wheels wear during interrupted grinding /N.I. Gun'ko // numerical processing methods: Sat. scientific. works. - Perm: Perm Polytechnic. In - t, 1971. - Vol. 97. - pp. 3 - 8. 11. Yakimov, A.V. Deep grinding of parts of circles with intermittent kubonita worktop / AV. Yakimov, AK Rahmani, AA Yakimov // Diamonds and superhard materials: science and tech. abstract Collection. - Moscow .: Institute of diamond, 1983. - Vol. 3. - pp. 8 -11. 12. Klimenko, N.N. Improving the performance of the creation of the wear parts of the surface layer of titanium carbide clad: dis. ... Cand. tehn. Sciences .: 05.02.08 / Klimenko Natalia. - Odessa, 2003. - 233 p.

\title{
Олексій Якімов, Любов Бовнегра, Сергій Уминський, Володимир Тонконогий, Юлія Шихірєва, Одеса, Україна
}

\section{ЗНОС ШЛІФУВАЛЬНИХ КРУГІВ З ПЕРЕРИВЧАСТОЮ РОБОЧОЮ ПОВЕРХНЕЮ}

\begin{abstract}
Анотація. Застосування кругів з переривчастою робочою поверхнею є ефективним засобом підвищення продуктивності $i$ зниження теплонапруженості процесу шліфування. Ці позитивні ефекти в значній мірі обумовлюються виникненням в пружній системі верстата високочастотних коливань, які полегшують процес стружкоутворення $і$ створюють умови для безперервного самоформування різального мікрорельєфу робочої поверхні абразивного інструменту. Однак при певних станах жорсткості пружної системи верстата, геометричних параметрів макрорельєфу робочої поверхні переривчастого круга $i$ параметрів режиму різання може виникнути параметричний резонанс, який супроводжується катастрофічним зносом абразивного інструменту та погірменням геометричних і фізико-механічних характеристик якості поверхневого шару оброблюваної деталі. Метою роботи є вивчення впливу параметрів режиму шліфування і геометричних параметрів робочої поверхні переривчастих абразивних кругів на їх розмірний $і$ лінійний знос, а також виявлення областей їх раціонального застосування. Встановлено, що коливання при переривчастому шліфуванні, викликані параметричних резонансом, можуть бути значно знижені або усунуті повністю за рахунок збільшення жорсткості пружної системи верстата, застосуванням переривчастих кругів певної геометрії, підвищенням окружної швидкості круга. На основі проведених експериментів по визначенню питомого зносу ельборових переривчастих кругів обтрунтовано дочільність їх використання при глибинному шліфуванні. Встановлено, що для підвищення розмірної стійкості абразивного інструменту необхідно підвищити окружну швидкість до $40 \mathrm{M} / \mathrm{c}$ i передбачити в верстатах можливість збереження сталості окружної швидкості круга в міру його зносу.
\end{abstract}

Ключові слова: розмірний знос; питомий знос; переривчасте шліфування; стабільне шліфування; глибинне шліфування; ріжучі виступи. 